\title{
Building a performance assessment model for social enterprises-views on social value creation
}

\author{
Chang-Lin Yang ${ }^{1,2,}$, Rong-Hwa Huang ${ }^{1}$, Yun-Chen Lee ${ }^{1}$ \\ ${ }^{1}$ Department of Business Administration, Fu Jen Catholic University, New Taipei City, Taiwan \\ ${ }^{2}$ Social Enterprise Research Center, Fu Jen Catholic University, New Taipei City, Taiwan
}

\section{Email address:}

051125@mail.fju.edu.tw (C. L. Yang),026299@mail.fju.edu.tw (R.H. Huang), badm2063@mails.fju.edu.tw (Y.C. Lee)

\section{To cite this article:}

Chang-Lin Yang, Rong-Hwa Huang, Yun-Chen Lee. Building a Performance Assessment Model for Social Enterprises-Views on Social Value Creation. Science Journal of Business and Management. Vol. 2, No. 1, 2014, pp. 1-9. doi: 10.11648/j.sjbm.20140201.11

\begin{abstract}
This study develops a comprehensive performance evaluation model that not only considers enterprise business operations but also presents conclusions regarding its social mission and impact. The performance measurement model includes three dimensions: essence of social enterprise, social impact and business operations. This study used analytic network process (ANP) to determine the importance weight of each dimension, issue and assessment indicator. The proposed model can hopefully help managers of social enterprises to achieve performance benchmarks. Furthermore, this study uses three case studies to demonstrate the practicability of the proposed performance measurement model. This study can also help social entrepreneurs achieve social missions.
\end{abstract}

Keywords: Social Enterprise, Social Impact, Performance Evaluation, Analytic Network Process

\section{Introduction}

As an emerging type of business organization with a social mission, social enterprises integrate business and social needs. Social enterprises begin with the introspection of capitalism. Owing to the exclusive emphasis on profit maximization, businesses lack the ability to create social value. Despite studies on the relationship between positive corporate image and healthy financial reports, negative factors such as excessive burdens on labor or production processes may adversely impact firm environment.

Under such circumstances, individuals with specific social concerns and objectives have established nonprofit organizations (NPOs) that comprise the third sector. While striving to resolve societal inequalities, not all NPOs are as effective as the Red Cross. While NPOs may have clear objectives, they often lack the operating funds necessary to achieve those objectives, largely because they rely on donations. External environmental circumstances easily influence the stability of external resources. Besides financial difficulties, NPOs also face management challenges, emphasizing the significance of business operating skills in a NPO.

Meanwhile, a new type of business entity has emerged in Europe and North America, commonly referred to as social enterprises. As business ventures created for social purposes, social enterprises mitigate either social problems or market failure, and also simply generate social value while operating with the financial discipline, innovation, and determination of a private sector business. Social enterprises have become an innovative means of solving social problems and social inequalities. The notion of "creating social value" provides great impetus to developing social enterprises. "Shared value" describes the creation of both economic and social value when attempting to solve social problems, which is equivalent to increasing total economic and social value (Porter \& Kramer, 2011).

Unfortunately, social enterprises suffer the same problems as NPOs. Some social enterprises cannot operate stably because they lack financial resources, or offer goods and services that are not in demand. Social enterprises cannot use their resources efficiently when management is inadequate. Therefore, the mission of the owner is also impossible to achieve. Recent studies have focused on evaluating social enterprise performance. Such studies aim to solve problems related to social enterprise management. The more popular models used to measure performance are social enterprise balanced score card (SEBC) and social return on investment (SROI) (Somers 2005; Norman and MacDonald 2004). 


\section{Literature Review}

\subsection{Social Enterprise}

Social enterprises are emerging in response to governmental failures, business that seek to extract excessive profits, and unstable NPOs. Dees (2001) stated that while the language of social entrepreneurship may be new, the phenomenon itself is not. Social entrepreneurs have always existed, though they have not always gone by the title.

Lane \& Casile (2011) defined a social enterprise as an organization whose organizational mission substantially involves remediation of some perceived social deficiency or creation of some social good. Such organizations seek to profit or to sustain themselves with minimal direct governmental support. Table 1 lists some of the definitions of social enterprises.

Table 1. Definitions of social enterprise

\begin{tabular}{ll}
\hline Authors & Definition of social enterprise \\
\hline Social Enterprise UK (2013) & $\begin{array}{l}\text { Social enterprises are businesses that trade to tackle social problems, improve communities, people's life chances, or } \\
\text { the environment. }\end{array}$ \\
Granados et al. (2011) & $\begin{array}{l}\text { Social enterprise involves social drivers that undertake innovative business operations to function as auto-sustainable } \\
\text { and guarantees the creation, sustainment, distribution and/or dissemination of social or environmental value }\end{array}$ \\
Mair \& Marti' (2006) & $\begin{array}{l}\text { Social entrepreneurship is broadly viewed as involving "the innovative use and combination of resources to pursue } \\
\text { opportunities to catalyze social change and/or address social needs." }\end{array}$ \\
Yunus (2006) & $\begin{array}{l}\text { Social business enterprise (SBE) regards a social enterprise as a business to create maximize social profit and help } \\
\text { individuals, yet not for personal benefits. }\end{array}$ \\
\hline
\end{tabular}

Social enterprises and for-profit companies differ mainly in goals and values. For-profit companies are focused on profit-maximization, and accordingly they are marketdriven. In contrast, social enterprises simultaneously pursue the triple button line. The operational goal of social enterprises is to maximize social-oriented profits. Therefore, social enterprises devote resources to creating social impact and social value.

By using a hybrid spectrum, Alter (2007) discussed the differences between social enterprises and for-profit companies (Figure 1). On the right of the spectrum are for-profit entities that create social value, but whose main motivations are profit creation and distribution to shareholders. Meanwhile, on the left of the spectrum are nonprofits whose commercial activities generate economic value that is diverted to fund social programs, but whose main motivation is mission accomplishment, as dictated by stakeholder mandate.

\begin{tabular}{|c|c|c|c|c|c|}
\hline \multicolumn{6}{|c|}{ Hybrid Spectrum } \\
\hline $\begin{array}{l}\text { Traditional } \\
\text { Nonprofit }\end{array}$ & $\begin{array}{c}\text { Nonprofit } \\
\text { With Income- } \\
\text { Generating } \\
\text { Activities }\end{array}$ & $\begin{array}{l}\text { Social } \\
\text { Enterprise }\end{array}$ & $\begin{array}{c}\text { Socially } \\
\text { Responsible } \\
\text { Business }\end{array}$ & $\begin{array}{c}\text { Corporation } \\
\text { Practicing } \\
\text { Social } \\
\text { Responsibility }\end{array}$ & $\begin{array}{l}\text { Traditional } \\
\text { For-Profit }\end{array}$ \\
\hline \multicolumn{3}{|c|}{$\begin{array}{r}\text { Mission Motive - } \\
\text { Stakeholder Accountability - }\end{array}$} & \multicolumn{3}{|c|}{$\begin{array}{l}\text { - Profit-making Motive } \\
\text { - Shareholder Accountability }\end{array}$} \\
\hline \multicolumn{3}{|c|}{$\begin{array}{l}\text { Income reinvested in social programs } \\
\text { or operational costs }\end{array}$} & \multicolumn{3}{|c|}{ - Profit redistributed to shareholders } \\
\hline
\end{tabular}

Figure 1. The Hybrid Spectrum (Alter 2007)

\subsection{Measurement of Social Enterprise Performance}

Different views exist regarding the best methods for measuring social enterprise performance. Clark \& Brennan (2012) developed the Balanced Value Matrix (BVM), which concludes that separate and balanced indicators exist for outputs (enterprise actions), outcomes (the benefits associated with enterprise actions), and impacts (the results enterprises desire). BVM starts with a value statement, the "why" behind the social venture. Kramer (2005) suggested that social enterprises can be scored in terms of five basic categories: social impact, aspiration and growth, entrepreneurship, innovation and sustainability. Moreover, Bagnoli \& Megali (2011) suggested that measurement of social enterprise performance should consider economic and financial performance, social effectiveness and institutional legitimacy.

The conventional models of performance measure are social enterprise social return on investment (SROI), social enterprise balanced score card (SEBC) and the SIMPLE model (social impact for local economies, SIMPLEs).

1. Social Return on Investment (SROI)

SROI is based on triple bottom line of social enterprises. Norman \& MacDonald (2004) speculated that the appropriateness of a 'bottom line' cannot yield a final performance figure, owing to the lack of a consistent measurement unit. One approach for non-quantified bottom lines is social return on investment (SROI) analysis. Developed by the Roberts Enterprise Development Fund (REDF) and tested by the New Economics Foundation (NEF 2004), this approach is based on traditional cost-benefit analysis. Assigning monetary values to social and environmental returns effectively demonstrates wider value creation.

Initially developed as an investment method, SROI utilizes a conventional managerial approach, which offers obvious advantages to social enterprises, since they are inherently predisposed to deliver wider social benefits. SROI determines the value of organizational social benefits, in relation to the costs of achieving those benefits, as illustrated below: 


$$
\text { SROI }=\frac{\text { Net Present Value of Benefits }}{\text { Net Present Value of Investment }}
$$

SROI provides a ratio of monetized social value, but this requires further explanation to be useful. SROI is designed to present a framework for exploring organization social impact by integrating both quantitative and qualitative approaches (NEF 2005). SROI can thus provide the starting point in a debate on social value creation (Rotheroe \& Richards 2007).

\section{Social Enterprise Balanced Scorecard (SEBC)}

Somers (2005) developed the SEBC model, which was modified from the Balanced Scorecard, proposed by Kaplan and Norton. SEBC introduced three changes: an additional layer to articulate social goals in addition to the financial ones already considered; the financial perspective was broadened to incorporate sustainability considerations; and the customer perspective was broadened to include numerous stakeholder groups.

In the SEBC model, social enterprises first stated the social goals that were their desired outcomes, and then progressed to other perspectives. From a financial sustainability perspective, each 'bubble' represented an objective. SEBC appears highly complex, and thus reflects the hybrid nature of social enterprises that demand more complex management systems. This predicament is most effectively demonstrated via the stakeholder perspective, which has been broadened from customers in the original model to distinguish those who purchase a service from those who consume it (i.e. donors, grant funders, employees, and the wider community).

In SEBC, a performance evaluation schedule should support every well-crafted strategy map. Meanwhile, the map should comprise an internally facing performance management scheme in which each objective is linked to a measure of success. For each objective there must be both a measure of success and an employee tasked with ensuring the objective is reached. The schedule thus becomes a communication medium to communicate performance internally, across teams or business units. Ultimately, once an organization has mapped its strategy through determining objectives and outcomes, performance measures must be incorporated into the SEBC framework to ensure strategy implementation throughout the organization.

3. Social Impact for Local Economies (SIMPLEs)

McLoughlin et al. (2009) developed the SIMPLE model, and found that not all impacts can be reduced to monetary measures that is, some impacts may be either impossible or undesirable. These impacts are also difficult to apply, especially for organizations with underdeveloped systems for impact measurement and reporting.

This SIMPLE model comprises four steps. These steps help SE managers to conceptualize the impact problem (i.e. SCOPE IT); identify and prioritize impacts as measurement targets (MAP IT), develop appropriate impact measures (TRACK IT), report impacts (TELL IT) and integrate the results into management decision making and organizational culture (EMBED IT). A five stage method based on the SIMPLE model is designed to simplify impact measurement into discrete and accessible parts to assist with training and management.

The proposed model features a 4BL approach to impact categorization, and thus embraces financial, economic, social and environmental impacts. These different impacts are further explained below in the Measurement Process Section. The SCOPE IT part of the SIMPLE impact model identifies four key drivers of impact: mission, external, internal and stakeholder drivers. The backward feedback loop emphasizes the linkages among impact measurement, ongoing business planning, and strategic management processes, and the use of these to continuously improve and maximize desired social impacts and minimize negative impacts.

\subsection{Social Value}

Porter \& Kramer (2006) proposed the notion of "Strategy \& Society" on Harvard Business Review (HBR). They asserted that a healthy society creates needs for businesses, and individual desire strengthens once needs are satisfied. Alternatively, successful companies, economic value and social value are the foundations of a healthy society. The notion of "creating social value", developed by Porter \& Kramer (2011) explains a deeper relationship between business and society, as well as stronger motivation to develop social enterprises.

Mair \& Martí (2006) also stated that social value creation is the main concern of social enterprises. Wood \& Leighton (2010) defined social value as referring to the wider non-financial impacts of programs, organizations and interventions, including the wellbeing of individuals and communities, promotion of social capital, and protection of the surrounding environment. These features are typically described as 'soft' outcomes, mainly owing to the difficulty of quantifying and measuring them.

\section{Model Construction}

This study is divided into three stages: preliminary model construction, preliminary model modification, and performance measure model construction.

\subsection{Preliminary Model Construction}

As discussed in the literature review, social enterprises are businesses that trade to tackle social problems, and thus exist to improve communities, life opportunities, or the environment. However, social enterprises require different performance measurement models to general businesses. This study proposes a multi-dimensional model which considers social enterprises in terms of their social mission and social changes. The performance measurement model also considers corporate operations. This study divides the performance measurement model into three dimensions: 
essence of social enterprise, social impact and business operations.

1. Essence of social enterprise

As the core of the measurement model, this dimension supports the social enterprise and maintains it on the right path. This model dimension refers to the relevant literature to measure two aspects of social enterprise performance, achievement of social mission, and performance in social entrepreneurship. Social mission and social entrepreneurship are the two main aspects of a business and a social enterprise.

2. Social Impact

A social enterprise aims to create social benefits. However, this dimension stresses the external effect that enterprise produces. Based on the features, this study refers to the literature to define two issues: social contribution and social outcome. Social contribution implies invisible benefits created by social enterprises, while social outcome denotes the visible outcomes achieved by a social enterprise.

3. Business Operations

The market test is one of the challenges a social enterprise must overcome. Most social enterprise managers lack adequate management skills and social relationships. However, this dimension is the foundation of social enterprise success. Based on the above features, this study refers to the pertinent literature to define three issues: firm survival, social relationship and future potential.

\subsection{Preliminary Model Modification}

Experts on social entrepreneurship, experts on government and scholars of social enterprises were asked to identify whether or not each proposed dimension, issue and factor was appropriate for evaluating social enterprise performance. The factor modification process followed the procedures suggested by Yang and Huang (2011). Experts first reviewed all factors, and individual factors were confirmed as appropriate if over 90 percent of the selected experts checked "appropriate" as a response. Factors that failed to reach the 90 percent threshold were deleted, while those that received evaluations between 80 to 90 percent and were marked "appropriate" but revisions were suggested, and were marked for revision revised according to the opinion of the reviewer.

Subsequent revisions were made after gathering expert advice. The evaluated model was divided into three levels. The first level comprised three dimensions; the second level comprised seven issues; and the third level comprised 32 performance indicators. These three dimensions are related to each other and related issue. The various indicators also affected one another. The relationship of the models is network structure. Figure 2 shows the modified model.

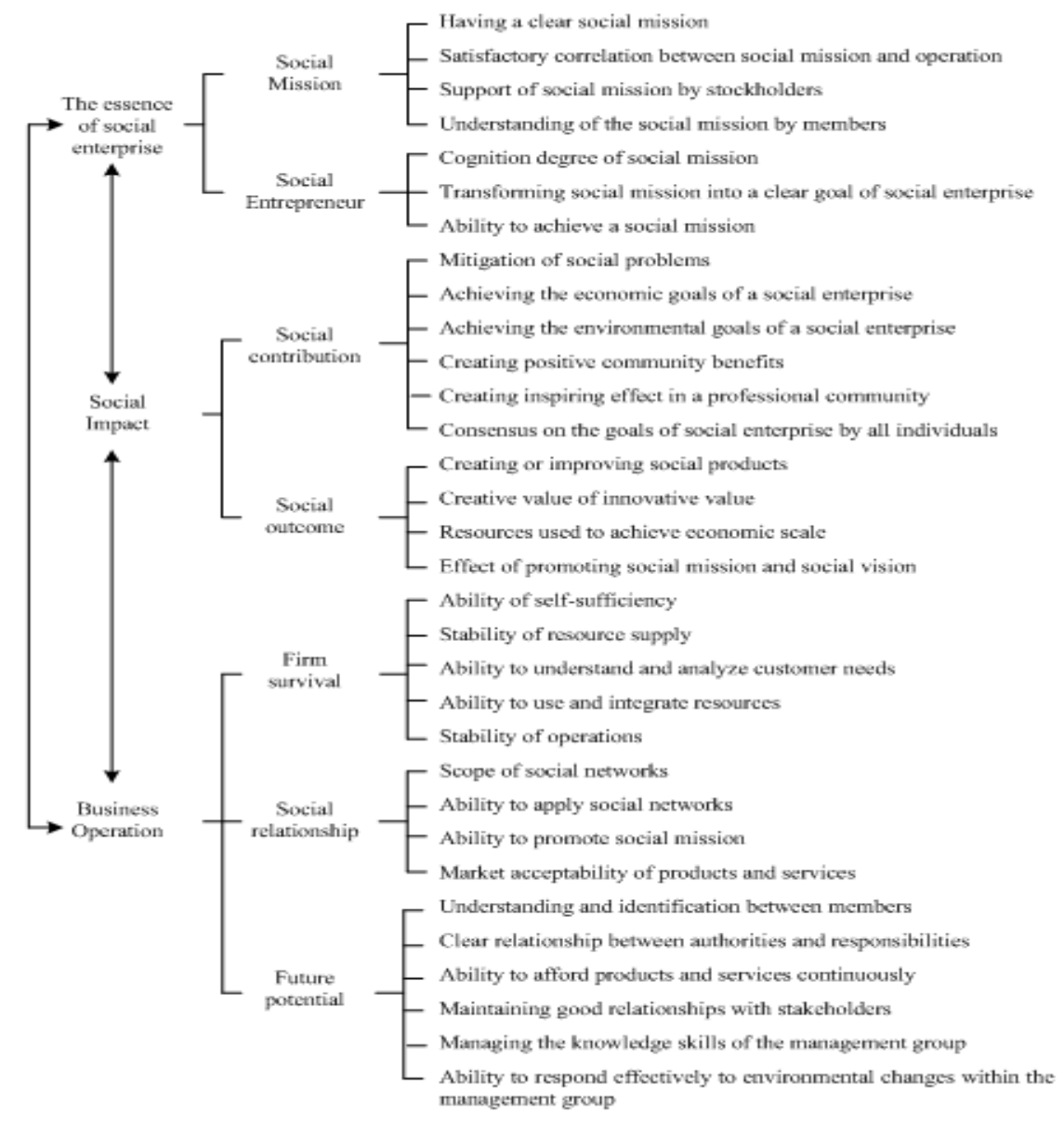

Figure 2. The modified model 


\subsection{Performance Evaluation Model Construction}

This study considers the internal dependencies and feedback relationships among indicators. Next, the network relationship is analyzed using the analytic network process (ANP) proposed by Saaty (2005) to determine the importance weight of each dimension, issue and indicator.
The ANP approach is a good alternative for evaluating dimensions, issues and assessment indicators that are interrelated (Carlucci \& Schiuma, 2009; Wu et al. 2009; Huang et al. 2012; Lee \& Yang, 2013).Table 2 lists the weights of each dimension, issue and assessment factor.

Table 2. The weights of major dimensions/issues/assessment factors

\begin{tabular}{|c|c|c|c|c|}
\hline $\begin{array}{l}\text { Dimensions } \\
\text { (weight*) }\end{array}$ & Issues (weight) & Assessment factors & $\begin{array}{l}\text { Factor } \\
\text { weight }\end{array}$ & $\begin{array}{l}\text { Dimension } \\
\text { weight }\end{array}$ \\
\hline \multirow{8}{*}{$\begin{array}{l}\text { The essence of } \\
\text { social enterprise } \\
(0.38)\end{array}$} & \multirow{4}{*}{ Social Mission (0.67) } & Having a clear social mission & 0.25 & 0.064 \\
\hline & & Satisfactory correlation between social mission and operation & 0.25 & 0.064 \\
\hline & & Support of social mission by stockholders & 0.25 & 0.064 \\
\hline & & Understanding of the social mission by members & 0.25 & 0.064 \\
\hline & \multirow{4}{*}{ Social Entrepreneur $(0.33)$} & Cognition degree of social mission & 0.26 & 0.033 \\
\hline & & Transforming social mission into a clear goal of social enterprise & 0.33 & 0.041 \\
\hline & & Ability to achieve a social mission & 0.41 & 0.051 \\
\hline & & Mitigation of social problems & 0.16 & 0.043 \\
\hline \multirow{8}{*}{$\begin{array}{l}\text { Social Impact } \\
(0.40)\end{array}$} & \multirow{5}{*}{ Social contribution $(0.67)$} & Achieving the economic goals of a social enterprise & 0.10 & 0.027 \\
\hline & & Achieving the environmental goals of a social enterprise & 0.16 & 0.043 \\
\hline & & Creating positive community benefits & 0.26 & 0.069 \\
\hline & & Creating inspiring effect in a professional community & 0.16 & 0.043 \\
\hline & & Consensus on the goals of social enterprise by all individuals & 0.16 & 0.043 \\
\hline & \multirow{4}{*}{ Social outcome $(0.33)$} & Creating or improving social products & 0.15 & 0.020 \\
\hline & & Creative value of innovative value & 0.19 & 0.025 \\
\hline & & Resources used to achieve economic scale & 0.23 & 0.030 \\
\hline \multirow{16}{*}{$\begin{array}{l}\text { Business Operation } \\
(0.22)\end{array}$} & & Effect of promoting social mission and social vision & 0.43 & 0.057 \\
\hline & \multirow{5}{*}{ Firm Survival (0.40) } & Ability of self-sufficiency to do what? & 0.19 & 0.017 \\
\hline & & Stability of resource supply & 0.13 & 0.011 \\
\hline & & Ability to understand and analyze customer needs & 0.19 & 0.017 \\
\hline & & Ability to use and integrate resources & 0.26 & 0.023 \\
\hline & & Stability of operations & 0.23 & 0.020 \\
\hline & \multirow{4}{*}{ Social relationship $(0.20)$} & Scope of social networks & 0.11 & 0.005 \\
\hline & & Ability to apply social networks & 0.26 & 0.011 \\
\hline & & Ability to promote social mission & 0.27 & 0.012 \\
\hline & & Market acceptability of products and services & 0.36 & 0.016 \\
\hline & \multirow{6}{*}{$\begin{array}{l}\text { Future potential } \\
(0.40)\end{array}$} & Understanding and identification between members & 0.11 & 0.009 \\
\hline & & Clear relationship between authorities and responsibilities & 0.10 & 0.009 \\
\hline & & Ability to afford products and services continuously & 0.16 & 0.014 \\
\hline & & Maintaining good relationships with stakeholders & 0.15 & 0.013 \\
\hline & & Managing the knowledge skills of the management group & 0.18 & 0.016 \\
\hline & & $\begin{array}{l}\text { Ability to respond effectively to environmental changes within the } \\
\text { management group }\end{array}$ & 0.30 & 0.026 \\
\hline
\end{tabular}

**The weights are rounded to the nearest hundredth.

\section{Discussion}

The results of the weighted value analysis indicate the importance of the three dimensions of the model for measuring social enterprise performance. The order of the performance weights is as follows: social impact (0.40), the essence of social enterprise $(0.38)$, and business operations (0.22).

According to the results, the weights of social impact and social enterprise essence exceed those of business operations. This finding implies that business operations are merely the foundation of a social enterprise. Creating social impact and keeping the original social mission are the main concerns. This finding matches predictions made using the preliminary model.

Regarding the essence of the social enterprise dimension, the weight of social mission (0.67) exceeds that of social entrepreneur (0.33). Social mission is the final goal of social enterprises, and thus a social enterprise should have a clear social mission. Social entrepreneurs must then practice this social mission. In terms of the social impact dimension, the weight of social contribution (0.67) exceeds that of social outcome (0.33). This result once again implies that solving social problems and creating social value is the main goal of 
social enterprises. Social enterprises can create invisible social contributions through creating visible social outcomes. In the business operations dimension, the weights of firm survival $(0.40)$ and future potential $(0.40)$ total 0.80 . Firm survival is the current priority of social enterprises, and future potential is the prospection of social enterprise. These two areas are major concerns for the business operations of social enterprises.

Based on factor weight, the top five factors are creating positive community benefits, having a clear social mission, satisfactory correlation between social mission and operations, support of social mission by stockholders, and understanding of the social mission by members are the main concerns. The outcome achieved is the same as discussed in the previous paragraph. Creating positive community benefits creates social contribution and can simultaneously create social value. Clear social mission that is supported by stockholders is also a priority. However, having a clear social mission is the first step in social enterprise operation. Realizing this first step allows social entrepreneurs to develop a business model for the social mission.

\section{Model Application and Empirical Analysis}

This study applied the constructed social enterprise performance measurement model to a practical case study involving three social enterprises - namely social enterprises $\mathrm{W}, \mathrm{O}$ and $\mathrm{T}$. The model was utilized to determine the practical performance of these three companies and to determine the model reliability. The results provide a reference for social enterprises or social entrepreneurs.

\subsection{Introduction to the Social Enterprises}

1. Social enterprise W: Social enterprise W was established in 2009 and mainly sells organic cotton clothing. The social mission of company $\mathrm{W}$ is to promote environmental protection. The organic cotton products are comparatively rare. Therefore, the founder of company $\mathrm{W}$ chooses organic cotton, which is free of industrial pollution, as the company's core product. Company W sells mainly online, and also promotes its social mission via the holiday environmental protection market.

2. Social enterprise $\mathrm{O}$ : Social enterprise $\mathrm{O}$ was established in 2007 and its core product is fair trade coffee. The social mission of company $\mathrm{O}$ is to promote social justice and environmental protection. The founder sees fair trade coffee as an opportunity to attract attention to the exploitation faced by coffee farmers. The major sales channel of company $\mathrm{O}$ is physical stores and online shops. Company $\mathrm{O}$ is also a coffee supplier and fair trade promoter.

3. Social enterprise $\mathrm{T}$ : Social enterprise $\mathrm{T}$ was established in 2010 and publishes magazines on behalf of the homeless or those in vulnerable housing environments. These marginalized persons also act as the sales force for the magazines. The social mission of company $\mathrm{T}$ is to offer homeless people the opportunity to earn legitimate incomes and to 'help them to help themselves'. The founder obtained authorization from the U.K. headquarters to establish a Taiwan operation. The magazines deal with popular music, international news, and information on the cultural and creative industries.

\subsection{Verification Process and Method}

The evaluation model used to evaluate social enterprise performance adopts a five-point Likert scale that ranges from "excellent", through "good", "normal", "bad", and finally "very bad". A three-member evaluation team comprised of a social entrepreneur and two researchers performs the evaluations. Scoring is performed by assigning 5 points to "excellent" ratings, 4 points to "good", 3 points to "normal", 2 points to "bad", and 1 point to "very bad". Following the questionnaires was collected and the total scores calculated using a weighted calculation, the three case study social enterprises were given their final total scores. Table 3 lists the results.

\subsection{Analysis of the Evaluation Results}

To comprehensively compare the evaluated performances of these three social enterprises in each area, each indicator is multiplied by its strategic weight and then the figures thus obtained are summed, to yield the overall evaluation shown in Fig. 3.

1. All of the three social enterprises received over four points in the social mission dimension, and company $\mathrm{W}$ scored slightly higher than the others. Looking at the indicator scores in detail, the score of "stockholder support of social mission" for company W clearly exceeded that for the other companies, which shows the stockholders of company W supported its social mission more strongly than was the case for the other companies.

2. All of the three social enterprises scored over four points in the social entrepreneur dimension. This result means that the social entrepreneurs of these three companies have high cognition regarding social mission, and thus their ability to achieve the social mission is also good.

3. All of the social enterprises scored similarly in the social contribution category, but in all cases the scores were less than 4 points. This result means that these three companies must improve their performance in mitigating social problems, achieving environmental goals, and reaching consensus among all stakeholders on social enterprise goals.

4. Company $\mathrm{W}$ scores higher than the other companies in the social outcome dimension. Looking at the various 
indicator scores in detail, company $\mathrm{W}$ clearly outscored the other companies in "Creating or improving social products". This result may be related to the product of company $\mathrm{W}$ being organic cotton $\mathrm{T}$ shirts. Owing to the rarity of organic cotton products in Taiwan, organic cotton $\mathrm{T}$ shirt have become a product that confers unique social status. Meanwhile, company $\mathrm{O}$ sells fair trade coffee. However, the fair trade concept appears not to be impressive to Taiwanese consumers, which reduce the effect of promoting social mission and social vision.

5. Company $\mathrm{T}$ scored lower in the firm survival issue than did other companies. Looking at the indicator scores in detail, company $\mathrm{T}$ scored lower than the other companies in "Ability to understand and analyze customer needs". The interview with the evaluation team revealed that this occurred because the concept of which the magazine sold by company $\mathrm{T}$ does not fit the preferences of its target customers.

6. Company $\mathrm{W}$ scores lower than the other companies in the social relationship dimension. Looking at the indicator scores in further detail, company W scored lower than the others in "Market acceptability of products and services". Most of the consumers of company $\mathrm{W}$ are people who accept the idea of organic cotton and environmental protection. The product of company $\mathrm{W}$ is less attractive to consumers who do not care for environmental protection.

7. All three social enterprises scored almost four points for the future potential dimension. This result means that the three companies have good business operations. Company scored lowest score in "Ability to finance continuous provision of products and services". This may be because innovation in coffee products is particularly challenging, and also because of the challenges associated with the promotion of the social mission of company $\mathrm{O}$.

In conclusion, this study advises that company $\mathrm{W}$ expand its involvement in health care channels to broaden its consumer market. Additionally, company $\mathrm{O}$ can add the producer story to its website to shorten the distance between its producers and consumers. Furthermore, company $\mathrm{T}$ can use economical intern projects to stimulate student interest, and can also use feedback from interns to improve its understanding of consumer needs.

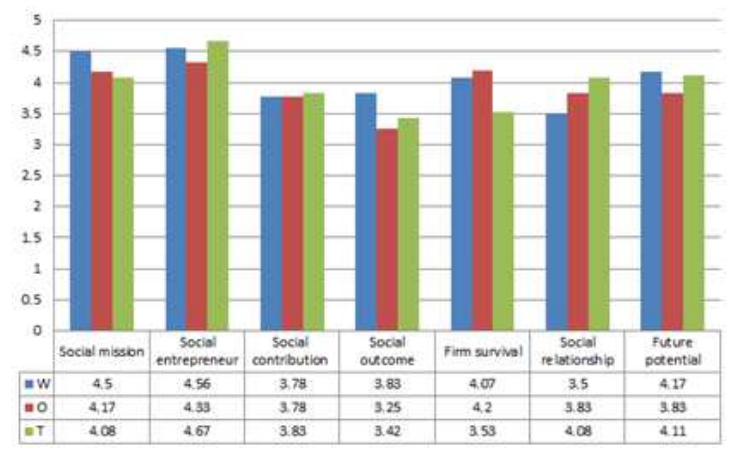

Figure 3. The practical performance histogram of social enterprise $W, O$ and $T$

Table 3. The empirical result of case social enterprises

\begin{tabular}{|c|c|c|c|c|c|c|c|c|}
\hline \multirow{2}{*}{ Dimensions } & \multirow{2}{*}{ Issues } & \multirow{2}{*}{ Assessment factors } & \multicolumn{3}{|c|}{ Original Score } & \multicolumn{3}{|c|}{ Weighted Score } \\
\hline & & & $\mathbf{W}$ & $\mathbf{O}$ & $\mathbf{T}$ & $\mathbf{W}$ & $\mathbf{O}$ & $\mathbf{T}$ \\
\hline \multirow{7}{*}{$\begin{array}{c}\text { The essence } \\
\text { of social } \\
\text { enterprise }\end{array}$} & \multirow{4}{*}{$\begin{array}{l}\text { Social } \\
\text { mission }\end{array}$} & Having a clear social mission & 4.67 & 4.67 & 4.33 & 0.299 & 0.299 & 0.277 \\
\hline & & Satisfactory correlation between social mission and operation & 4 & 4.67 & 4.33 & 0.256 & 0.299 & 0.277 \\
\hline & & Support of social mission by stockholders & 4.67 & 3.33 & 3.67 & 0.299 & 0.213 & 0.235 \\
\hline & & Understanding of the social mission by members & 4.67 & 4 & 4 & 0.299 & 0.256 & 0.256 \\
\hline & \multirow{3}{*}{$\begin{array}{c}\text { Social } \\
\text { entrepreneur }\end{array}$} & Cognition degree of social mission & 5 & 4.67 & 4.67 & 0.165 & 0.154 & 0.154 \\
\hline & & Transforming social mission into a clear goal of social enterprise & 4.67 & 4.33 & 4.33 & 0.191 & 0.178 & 0.178 \\
\hline & & Ability to achieve a social mission & 4 & 4 & 5 & 0.204 & 0.204 & 0.255 \\
\hline \multirow{10}{*}{$\begin{array}{l}\text { Social } \\
\text { impact }\end{array}$} & \multirow{6}{*}{$\begin{array}{c}\text { Social } \\
\text { contribution }\end{array}$} & Mitigation of social problems & 3.33 & 3.67 & 4 & 0.143 & 0.158 & 0.172 \\
\hline & & Achieving the economic goals of a social enterprise & 3.33 & 3.67 & 4.33 & 0.09 & 0.099 & 0.117 \\
\hline & & Achieving the environmental goals of a social enterprise & 4.33 & 4.33 & 3 & 0.186 & 0.186 & 0.129 \\
\hline & & Creating positive community benefits & 3.67 & 3 & 3.33 & 0.253 & 0.207 & 0.23 \\
\hline & & Creating inspiring effect in a professional community & 4 & 4 & 4.33 & 0.172 & 0.172 & 0.186 \\
\hline & & Consensus on the goals of social enterprise by all individuals & 4 & 4 & 4 & 0.172 & 0.172 & 0.172 \\
\hline & \multirow{4}{*}{$\begin{array}{c}\text { Social } \\
\text { outcome }\end{array}$} & Creating or improving social products & 4 & 3.33 & 3 & 0.08 & 0.067 & 0.06 \\
\hline & & Creative value of innovative value & 3.33 & 2.67 & 3.33 & 0.083 & 0.067 & 0.083 \\
\hline & & Resources used to achieve economic scale & 4.33 & 4 & 3.67 & 0.13 & 0.12 & 0.11 \\
\hline & & Effect of promoting social mission and social vision & 3.67 & 3 & 3.67 & 0.209 & 0.171 & 0.209 \\
\hline
\end{tabular}




\begin{tabular}{|c|c|c|c|c|c|c|c|c|}
\hline \multirow{2}{*}{ Dimensions } & \multirow{2}{*}{ Issues } & \multirow{2}{*}{ Assessment factors } & \multicolumn{3}{|c|}{ Original Score } & \multicolumn{3}{|c|}{ Weighted Score } \\
\hline & & & W & $\mathbf{O}$ & $\mathbf{T}$ & $\mathbf{W}$ & $\mathbf{O}$ & $\mathbf{T}$ \\
\hline \multirow{15}{*}{$\begin{array}{l}\text { Business } \\
\text { operation }\end{array}$} & \multirow{5}{*}{$\begin{array}{c}\text { Firm } \\
\text { survival }\end{array}$} & Ability of self-sufficiency to do what? & 4.33 & 4.33 & 4.33 & 0.074 & 0.074 & 0.074 \\
\hline & & Stability of resource supply & 3.67 & 4.67 & 4 & 0.04 & 0.051 & 0.044 \\
\hline & & Ability to understand and analyze customer needs & 4 & 3.33 & 2.33 & 0.068 & 0.057 & 0.04 \\
\hline & & Ability to use and integrate resources & 4 & 4.33 & 2.33 & 0.092 & 0.1 & 0.054 \\
\hline & & Stability of operations & 4.33 & 4.33 & 4.67 & 0.087 & 0.087 & 0.093 \\
\hline & \multirow{4}{*}{$\begin{array}{l}\text { Social } \\
\text { relationship }\end{array}$} & Scope of social networks & 3.33 & 3.67 & 4 & 0.017 & 0.018 & 0.02 \\
\hline & & Ability to apply social networks & 4 & 4 & 4.33 & 0.044 & 0.044 & 0.048 \\
\hline & & Ability to promote social mission & 3.33 & 3.67 & 3.67 & 0.04 & 0.044 & 0.044 \\
\hline & & Market acceptability of products and services & 3.33 & 4 & 4.33 & 0.053 & 0.064 & 0.069 \\
\hline & \multirow{6}{*}{$\begin{array}{l}\text { Future } \\
\text { potential }\end{array}$} & Understanding and identification between members & 4.67 & 4.33 & 6.67 & 0.042 & 0.039 & 0.033 \\
\hline & & Clear relationship between authorities and responsibilities & 4 & 4 & 4.33 & 0.036 & 0.036 & 0.039 \\
\hline & & Ability to afford products and services continuously & 4.33 & 3.33 & 4 & 0.061 & 0.047 & 0.056 \\
\hline & & Maintaining good relationships with stakeholders & 4.33 & 4 & 3.67 & 0.056 & 0.052 & 0.048 \\
\hline & & Managing the knowledge skills of the management group & 3.67 & 3.67 & 4.67 & 0.059 & 0.059 & 0.075 \\
\hline & & $\begin{array}{l}\text { Ability to respond effectively to environmental changes within the } \\
\text { management group }\end{array}$ & 4 & 3.67 & 4.33 & 0.01 & 0.095 & 0.113 \\
\hline
\end{tabular}

\section{Conclusions}

This study gathered significant amounts of data on social enterprise performance, integrated comments from experts in relevant fields, developed assessment constructs and performance measurement indicators, and estimated the weights of those indicators. Analytic network process (ANP) is also adopted, with a focus on the relationships among measurable dimensions, issues and assessment indicators. The mutual influences of these indicators are visible, and the evaluation index is calculated accordingly to examine the influences of issues such as social mission, social entrepreneur, social contribution and social relationship on social enterprise performance.

Besides helping social entrepreneurs assess their own social enterprises, performance evaluation models can also provide them a clear path to better understanding their own social enterprises.

\section{Acknowledgements}

The authors would like to thank the National Science Council of the Republic of China, Taiwan for financially supporting this research under Contract No. NSC 101-2632-H-030-001-MY3.

\section{References}

[1] Alter, K. (2007), Social enterprise typology, United State: Virtur Ventures LLC.

[2] Bagnoli, L., \& Megali, C. (2011), Measuring Performance in Social Enterprises. Nonprofit and Voluntary, Sector Quarterly, 40(1), 149-165.

[3] Carlucci, D., \& Schiuma, G., (2009), Applying the analytic network process to disclose knowledge assets value creation dynamics. Expert Systems with Applications, 36(4), 7687-7694.

[4] Clark, C. \& Brennan, L. (2012) Entrepreneurship with social value: a conceptual model for performance measurement. Academy of Entrepreneurship Journal, 18(2), 17-39.

[5] Dees, J.G. (2001), The Meaning of "Social Entrepreneurship", Center for the Advancement of Social Entrepreneurship, Fuqua School of Business, Duke University, search date: 2012.10.27, From: http://www.caseatduke.org/ documents/ dees_sedef.pdf

[6] Granados, M.L., Hlupic V, Coakes E., \& Mohamed, S., (2011), Social enterprise and social entrepreneurship research and theory: A bibliometric analysis from 1991 to 2010. Social Enterprise Journal, 7(3), 198-218.

[7] Huang, R.H., Yang, C.L., \& Kao, C.S., (2012), Assessment Model for Equipment Risk Management: Petrochemical Industry Cases. Safety Science, 50(4), 1056-1066.

[8] Kramer, M.R., (2005), Measuring Innovation: Evaluation in the Field of Social Entrepreneurship, United State: Foundation Strategy Group.

[9] Lane, M.D., \& Casile, M. (2011), Angels on the head of a pin The SAC framework for performance measurement in social entrepreneurship ventures. Social Enterprise Journal, 7(3), 238-258.

[10] Lee, L.M., \& Yang , C.L., (2013), Key Success Factors in Female Micro Entrepreneurship. Service Science and Management Research, 2(3), 39-47.

[11] Mair, J.. \& Mart1', I. (2006), Social entrepreneurship research a source of explanation, prediction, and delight. Journal of World Business, 41(1), 36-44.

[12] McLoughlin, J., Kaminski, J., Sodagar, B., Sabina K., Harris, R., Arnaudo, G., \& Mc Brearty, S. (2009), A strategic approach to social impact measurement of social enterprises: The SIMPLE methodology. Social Enterprise Journal, 5(2), 154-178. 
[13] New Economics Foundation, (2004), Social Return on Investment: Valuing what matters; findings and recommendations from a pilot study, London, New Economics Foundation. http://www.neweconomics.org/gen/uploads/ ck3oqu45 15ubcv55e1xhminn21042004165114.pdf (15/11/12).

[14] New Economics Foundation, (2005), Measuring value creation in Social Firms: a do-it-yourself training manual for SROI.

[15] Norman, W., \& MacDonald. C., (2004), Getting to the Bottom of Triple Bottom Line. Business Ethics Quarterly, 14(2), 243-262.

[16] Porter, M.E., \& Kramer, M.R., (2006), Strategy and society: the link between corporate social responsibility and competitive advantage. Harvard Business Review, 84(12), 78-92.

[17] Porter, M.E., \& Kramer, M.R., (2011), The big idea: creating shared value. Harvard Business Review, 89(1), 1-17.

[18] Rotheroe, N., \& Richards, A., (2007), Social return on investment and social enterprise: transparent accountability for sustainable development. Social Enterprise Journal, 3(1), $31-48$.
[19] Saaty T. L., (2005), Theory and applications of the analytic network process: decision making with benefits, opportunities, costs, and risks.USA: RWS Publication.

[20] Social Enterprise UK, (2013), search date: 2013.06.11, From:http://www.socialenterprise.org.uk/about.

[21] Somers, A., (2005), Shaping the balanced scorecard for use in UK social enterprises. Social Enterprise Journal, 1(1), 43-56.

[22] Wood C., \& Leighton D., (2010), Measuring Social Value: The Gap between policy and practice. London, UK: Demos.

[23] Wu, W.Y., Shih, H.A., \& Chan, H.C., (2009), The analytic network process for partner selection criteria in strategic alliances. Expert Systems with Applications, 36(3), 4646-4653.

[24] Yang, C.L., \& Huang, R.H., (2011), Key success factors for online auctions: analysis of auctions of fashion clothing. Expert Systems with Applications, 38(6), 7774-7783

[25] Yunus, M., (2006), Social Business Entrepreneurs are the Solution. Oxford: Said School of Business, University of Oxford. 